DOI https://doi.org/10.36059/978-966-397-154-4/46-66

\title{
GLOBAL CHANGE IN CLIMATE AND ITS EFFECT ON THE FORMATION OF CROPS IN SOUTHERN STEPPE OF UKRAINE
}

\section{Holoborodko S. P.}

\section{INTRODUCTION}

The study of the Intergovernmental Panel on Climate Change (IPCC) under the UNO, which was proved by the national academies of the countries of the Group of Seven, determined that in comparison to the year of the start of industrial revolution (1850) the average temperature of the Earth increased $0.7^{\circ} \mathrm{C}$ and it is within $+15^{\circ} \mathrm{C}$ that supports the existence of sustainable biogeocenosis on the planet ${ }^{1}$. It was determined by the assessment of the climatic models of IPCC that in XXI century the average temperature of the Earth can possibly rise up by $1.1-6.4^{\circ} \mathrm{C}$, which will lead to the warming and elevation of the World Ocean level through a thousand years. The increase of the global temperature on the Earth will lead to the change in amounts and distribution of precipitation and more frequent occurrence of natural disasters such as flooding, drought, hurricane, etc., that will cause the decrease or complete destruction of the crops and to the extinction of many biological species of plants and animals. Herewith, global change in climate will be favorable for the increase of frequency and scale of the above-mentioned phenomena ${ }^{2}$.

The reason of the global change in climate on the Earth is studied by many countries at the moment; however, in most cases they are fragmental and often are in a contrary to each other but are also the same in many things. The paleontological studies of IPCC in the change of the water level in the World Ocean for the last 0.5 million years and in the determination of the Oxygen isotope concentration in the sea water $\left({ }^{18} \mathrm{O}\right)$ and Carbon dioxide $\left(\mathrm{CO}_{2}\right)$ in the Antarctic ice revealed the presence of long-term climatic cycles, which in the Quarternary period took the form of periodical frozen and

1 Исследования межгосударственной группы экспертов при ООН. [Электронный pecypc]. Начало повышения температуры на планете. Режим доступа: Internet resources: http://ru.wikipedia.org/wiki/.

2 Влияние парниковых газов на глобальное изменение климата. [Электронный pecypc]. Причины нагревания поверхности Земли. Режим доступа: Internet resources: http://www.referatik.com.ua/subject/97/41350/?page=2. 
coincide with inter-ice temperature maximums. The main reasons of the above-mentioned changes in climate in time are still studied insufficiently, however, there are several ones with accordance to present scientific models: change of the Earth orbit around the Sun (the cycles of Milankovich), volcanic dust, change of the sun activity and greenhouse effect ${ }^{3}$. For the first time greenhouse effect has been defined by Joseph Fourier in 1824, and it was quantitatively determined by Svante Arrhenius in 1896. The latter is determined by considerable emissions of Carbon dioxide $\left(\mathrm{CO}_{2}\right)$, methane $\left(\mathrm{CH}_{4}\right)$ and Nitrous oxide $\left(\mathrm{N}_{2} \mathrm{O}\right)$ in the atmosphere, at the absorption of which infrared emanation takes place that causes heating both of the atmosphere and the surface of the planet. The main greenhouse gases on the Earth are: water vapor (36-70 Carbon dioxide $\left(\mathrm{CO}_{2}\right)$ (9-26\%), methane $\left(\mathrm{CH}_{4}\right)$ (4-9\%) and tropospheric ozone $\left(\mathrm{O}_{3}\right)$ (3-7\%). All the mentioned gases, including Fluor and Chloral hydrates, are called greenhouse in general. In comparison to the beginning of the industrial revolution in the middle of XVIII century (1850 p.), since the beginning of which more than 150 years have passed, concentration of $\mathrm{CO}_{2}$ in the atmosphere of the Earth increased by $31 \%$, and $\mathrm{CH}_{4}$ by $149 \%{ }^{4}$. At the same time, all the pollution sources of the atmospheric space (coal electricity stations, the tubes of metallurgic plants, car outlets, etc.) emit up to 22 milliard tons of greenhouse gases each year ${ }^{5}$. Besides, at the application of fertilizers, burning of coal, natural gas and oil, changes of agrolandscapes, firstly, disforesting and plowing of natural meadows, up to 250 million tons of $\left(\mathrm{CH}_{4}\right)$ emit to the atmosphere each year. This is caused by the fact that the surface of the land without plants, comparatively to the plant-settled one, is heated stronger that causes the increase of water vapor condensation of precipitation and leads to the decrease of their amounts, the occurrence of drought.

The effect of greenhouse gases, first of all, Carbon dioxide of his stable isotopes $\left({ }^{12} \mathrm{C}\right.$ and $\left.{ }^{13} \mathrm{C}\right)$ and a radioactive one $\left({ }^{14} \mathrm{C}\right)$ with a half-life of 5730 years, on the global change in climate consists in that they absorb and transfer to all the directions the part of infrared radiation, coming to the surface of the Earth. This is the reason of the increase of their concentration in the atmosphere, which is absorbed by greenhouse gases, in consequence

\footnotetext{
${ }^{3}$ Гидрологический словарь. Под ред. В.М. Котлякова. Л.: Гидрометиздат, 1984. 527 с.

${ }^{4}$ Концентрация углекислого газа в атмосфере. [Электронный ресурс]. Изменение структуры агроландшафтов. Режим доступа: Internet resources: http://enrin.grida.no/ htmls/tadjik/ntalgraphics/rus/html/climate.htm.

5 Источники загрязнения атмосферы. [Электронный ресурс]. Ежегодные выбросы парниковых газов. Режим доступа: Internet resources: http://www.ukragroconsult.com/ contentview/46301/61/.
} 
of the heating of the lower layers of troposphere and the surface of the Earth happens ${ }^{6}$.

The history of the Carbon cycle on the Earth is currently studied sufficiently by the isotopes of Carbon and its relative distribution in sedimentary rocks. It stems from the data that Carbon cycle had long periodical changes that correlated with the ages of soil formation. At the time of tectonic moves activation, the sediments of Carbonate rocks strengthened and its isotopic content became heavier that corresponded to the increase of Carbon drift from the core source, which mainly contains enriched Oxygen. Therefore it is believed that the main measurements of the Carbon cycle were through the strengthening of the erosion of the continents as a result of mountains formation.

\section{State of the problem study}

Nowadays, the history of the change of Carbon dioxide $\left(\mathrm{CO}_{2}\right)$ and methane $\left(\mathrm{CH}_{4}\right)$ content in the atmosphere in the Quarternary period is relatively well studied from the surface glaciers of Greenland and Antarctica. The Quarternary period is distinguished from other geological periods by the cyclic epochs of ice and inter-ice ages when the changes in climate distinctly correlated with the changes of the Carbon cycle. At the same time, even in this most studied period there is no sufficient clarity about the reasons of cyclic changes on the Earth and the connection of geochemical changes with climatic ones. It is determined that the Quartenary period was characterized with four frozen, which with the period up to 100 thousand years took place one by one. Herewith, atmospheric content of $\mathrm{CO}_{2}$ and $\mathrm{CH}_{4}$ changed with the accordance to the variations of temperature that resulted in the determination of the following statements:

1. All the Quartenary frozen took place with the period of nearly 100 thousand years.

2. Each ice age was accompanied by the decrease of the concentration of Carbon dioxide $\left(\mathrm{CO}_{2}\right)$ and methane $\left(\mathrm{CH}_{4}\right)$ in the atmosphere.

3. Inter-ice ages began with the sharp, momentarily in the geological scale, increase of the concentration of $\mathrm{CO}_{2}$ and $\mathrm{CH}_{4}$.

4. At the time of inter-ice ages there was a gradient of the methane $\left(\mathrm{CH}_{4}\right)$ concentration between Northern and Southern hemispheres that is proved by the content of the air got form the glaciers of Greenland that were significantly higher than Antarctic ones. During the ice ages the

\footnotetext{
${ }^{6}$ Поглощение инфракрасной радиации. [Електронний ресурс]. Причины увеличения концентрации парникових газов. Режим доступу: www.un.org/ru/documents/decl_conv/ conventions/agenda21_ch12b.shtml.
} 
concentration of methane $\left(\mathrm{CH}_{4}\right)$ in the both hemispheres decreased and gradually evened.

5. During the ice ages the content of light Carbon isotope decreased.

The development of frozen led to the decrease of the biomass of surface biosphere, and as all plants selectively absorbed the light Carbon isotope from the atmosphere, at the coming of ice ages all the light Carbon emitted to the atmosphere, and through it to the Ocean. Based on the modern biosphere, its average isotopic content and analogical data of the Ocean, and knowing the changes of isotopic content from the remnants of sea organisms at the time of ice ages it was calculated the change of the surface biomass of the previous ice ages. Such estimations were conducted and reached 400 tons in comparison to the modern mass. In this way, the change of isotopic content of Carbon in the nature of the Earth were defined.

All the Quartenary frozen were developed in Northern hemisphere where there are greater continental landscapes. There were mostly oceans in Southern hemisphere and there were almost no big marshes - the sources of methane, because marshes are concentrated only in Northern boreal belts ${ }^{7}$.

The development of frozen led to the decrease of the size of Northern marshes - one of the main sources of methane $\left(\mathrm{CH}_{4}\right)$ and at the same time absorbents of Carbon dioxidei $\left(\mathrm{CO}_{2}\right)$. Therefore, during the inter-ice ages, when the area of marshes was the maximum in Northern hemisphere, the concentration of methane in the atmosphere was always higher that is explained by the presence of methane concentration gradient between the hemispheres in the inter-ice ages ${ }^{8}$.

Anthropogenic activity of humankind made new inputs in the cycle of Carbon. With the beginning of industrial era, people began to burn the mineral fuels: coal, oil and gas, which were stored for the million years of the Earth existence. Human activity caused significant changes in land-use: disforesting, plowing of the herbage of natural grasslands, marshes drainage, flooding of the previously dry lands, etc. Because the history of the planet consists of grandiose events, talking about the change of the Carbon cycle by the man we have to adjust the scales and duration of these effects with the events of the past. Some of these facts are found out but the reason-cause connections still have no response. A number of researchers state that the change in climate on the Earth occurs within the boards of its own natural variability and is caused by the repetitive processes that take place in the

\footnotetext{
${ }_{8}^{7}$ Мачерет Ю.П. Радиозондирование ледников. М.: Науч. мир, 2006. 392 с.

8 Причины увеличения метана в атмосфере. [Электронный ресурс]. Наличие градиента концентрации метана в межледниковые периоды. Режим доступа: Internet resources: http://www/lib/ua-ru/net/inode/p-2/14290.html.
} 
system Earth - the Sun - Space. By the existent in climatology classification of the cycles of climate there are four groups of them: super long - 150300 million years, longi - 10-50 million years, short - hundreds and thousands years, and ultra-short connected with the activity of the Sun and are measured within $2400,200,90$, and 11 years ${ }^{9}$. The existing models of global climatic change testify that the determined rhythms of the Sun at the time are determinative in the increase of the temperature on the Earth and in the World Ocean. At the same time, global increase of the average temperature of the Earth and the World Ocean does not mean warming of climate everywhere and in any time. According to one of the IPCC models, global warming on the Earth will lead to partial weakening or, perhaps, will completely stop the Gulf Stream that will affect on considerable decrease of the average temperature in Europe. IPCC also related to the negative changes in climate of Europe in 2001 in Shanghai the increase of temperatures and drought periods in the South, shortening of snow cover and recession of mountain glaciers, increase of strong floods and high waters on the rivers; the increase in Central and Eastern Europe of summer precipitation, forest and peat fire occurrence, diminishing of forest productivity, increase in soil erosion in Northern Europe. In Arctic catastrophic decrease of the area of full ice cover, diminishing of the areas of sea ice, increased erosion of the banks ${ }^{10}$.

In the historical aspect of the Earth, slowing down of the Gulf Stream is connected with ice ages - relatively long stages in the geological history of the planet, during which on the arena of general relative cooling of climate there were many times during which the interchange of sharp cooling periods, accompanied with the intensive ice-covering, and relative warming during which continental ices diminished in their sizes that is observed at the moment in Arctic and Antarctica. The coming of small ice age was connected with slowing down of the Gulf Stream, which had begun after 1300. Beginning from 1300, Western Europe, as it was determined, survived an ecological catastrophe. Intensive rainfall in the summer and severe winters resulted in the ruin of crops for several consequent years, because of this, orchards and vineyards were destroyed by frost in England, Scotland, Northern France and Germany. The consequence of the first stage of the small ice age in the first half of XIV century was starvation in the countries of Europe, which partially finished just after 1370. Relative warming of the

\footnotetext{
${ }^{9}$ Природная изменчивость процесса Солнце-Земля. [Электронный ресурс]. Циклы изменения климата. Режим доступа: Internet resources: http://www.ukrindustrial.com./news/ index.php.?newsid=219087.

${ }_{10}$ Уменьшение площади ледников Арктики. [Электронный ресурс]. Усиление эрозии морских берегов. Режим доступа: Internet resources: http://www.zn.ua/3000/3320/63430/.
} 
climate in the countries of Western and Central Europe was just in the second stage of the small ice age in the beginning and middle of XVI century, when the maximum activity of the Sun partially extinguished the negative process of the Gulf Stream slowing down. The coldest period of the small ice age was its third stage, which lasted during the end of XVI beginning of XIX century, when the decreased activity of the Gulf Stream coincided in time with the lowest level of the sun activity. In the countries of Southern Europe in this period almost every year severe and long winters repeated, during which in 1621-1629 the Bosporus was frozen, and in 1709 the Adriatic Sea was frozen near the banks ${ }^{11}$.

The coldest year was 1665, when in the winter of 1664-1665 birds were frozen during the flight in the air in Germany and France. High mortality was observed in all the European countries, the population of Scotland and Estonia decreased by $30 \%$ and of Finland - by 50\%. The anomalous wave of cooling in the countries of Europe also took place in 1740-1784, when stable cold weather with snow and ice cover was observed in Germany, Swiss and France with the air temperature $-7-10^{\circ} \mathrm{C}$ that lasted to the end of April ${ }^{12}$.

Therefore, the admirers of the theory of small ice age state that current warming on the Earth is the natural escape from the ice age of XIVXIX centuries that will lead to the renovation of the temperatures of the Atlantic optimum.

Together with the cold geological period, there was a manifestation of sudden warming that was nearly 55-65 million years ago, and was accompanied by significant change of the atmosphere and extinction of a number of plants and animals ${ }^{13}$. With accordance to paleoclimatic investigations, the temperature on all the continents of the Earth at the time of thermal maximum reached $20^{\circ} \mathrm{C}$ that is by $1,5^{\circ} \mathrm{C}$ more than the current value, and in the seas of Arctic warming happened in larger dimensions than nowadays. Duration of the late-paleocenic thermal maximum lasted for more than 200 thousand years, and it is impossible to reliably determine the reason of this geological event till now. One of the models for this phenomenon could be dramatic increase of Carbon dioxide $\left(\mathrm{CO}_{2}\right)$ in the atmosphere that reached $2-3 \%$ (the current is $0.038 \%$ ) and, especially, methane $\left(\mathrm{CH}_{4}\right)$, the

${ }^{11}$ Фазы ледниковых периодов. [Электронный ресурс]. Продолжительность зимних периодов в Европе. Режим доступа: Internet resources: http://www.podrobnosti.ua.health/ 2008.08.22/548886.html.

12 Аномальне похолодання в Европе. [Электронный ресурс]. величение продолжительности зимного периода. Режим доступа: Internet resources: http://www.grida.no/climate/ipec_tor/vol14/russian/083.htm

13 Палеонтологические исследования. [Электронный ресурс]. Причины вымерания отдельных видов растений и животных. Режим доступа: Internet resources: http://imm.org.ua/se/news/index.php?action=show\&nid=4163 
increase of the concentration of which in the atmosphere dominated in the early history of the Earth and could cause global warming.

During the largest thermal maximum that took place on the Earth more than 65 million years ago, there took place a global change in the biosphere, which resulted in the extinction of many species of mammals, and they were replaced by the species of modern type. Duration of natural Carbon abnormality and its complete disappearance lasted for 150 thousand years, after which the Earth returned to its normal state.

The analysis of the extreme situation, which occurred in nature and agricultural production of different countries of the world this time, certifies about the fact that the reason of the change in climate of the Earth and its catastrophic consequence is still insufficiently studied because the first reason of the phenomenon is not clarified.

One of the reasons that caused the change of geochemical cycle in the nature of greenhouse gases, first of all, Carbon dioxide $\left(\mathrm{CO}_{2}\right)$ and methane $\left(\mathrm{CH}_{4}\right)$, is the disturbance of the regular process of continuous energy exchange of the space system the Earth-the Sun, by the human activity connected with the mining of oil from interior of the Earth ${ }^{14}$. The world oil consumption at the beginning of XXI century (2004-2005) reached 3031 milliard barrels per year, and the opened new storages during these years do not overcome 8 milliard barrels and exceeding of the mining over the consumption was only 2 million barrels a day. That is why because in XXI century the search for the replacement energy sources for oil, but as the search for the alternative energy sources is difficult, long and expensive, the oil mining from the interior of the Earth is going on all the time. By the data of scientific works of the National Academy of Sciences of Ukraine, the oil formation on the planet Earth has inorganic origin and gets through consequent geocosmoplasmochemical processes performing donor-acceptor function between the movements of electrons from the surface of the Earth to its core. Based on the physic-chemical properties of Carbon, $87 \%$ of which is in the composition of oil, the process of core synthesis on the surface of the planet core is provided, and therefore geocosmoplasmochemical process of new substance. Therefore, in the regions of intensive oil mining the sustainably existent link is destroyed resulting in the increase of electric conductivity with ionosphere that causes the increase of greenhouse effect and the acceleration of the climate change on the Earth. The latter causes storms, typhoons, tornadoes, intensive melting of the icecover firstly of Arctic and Antarctic. Therefore, the increase of the average

\footnotetext{
${ }^{14}$ Bentley R. W. Global oil and gas depletion: an overview. Energy Pochy. 2002. № 30. P. 189-205.
} 
temperature of the Earth during the last 50 years was found to be twice bigger than at the last 100 years. Herewith, it is warming two times faster in Arctic than in other climatic zones because of the zone of spreading the ice just in the last 30 years by every decade decreased by $2.7 \%$. If greenhouse gases in XXI century will emit to the atmosphere in the same amount as now then the average temperature on the planet will reach $2-4^{\circ} \mathrm{C}$ that might cause the extinction of $20-30 \%$ species of existent animals and plants in different biocenosis. At the same time, the level of water in the World Ocean is rising, which became $17 \mathrm{~cm}$ higher during the last $\mathrm{XX}$ ccentury or higher than during the previous 2000 years.

At the same time, Danish ecologist Bjorn Lomborg considers that the process of global warming on the Earth is connected not only with anthropogenic activity but with the internal processes that take place inside the planet and are connected with the continents movement. At the moment, there were discovered on the bottom of oceans thousands of hydrothermal sources "black smokers" with the height of up to 120 meters and up to 200 meters in diameter, which are continuously emitting tons of greenhouse gases in the atmosphere, such as Carbon dioxide $\left(\mathrm{CO}_{2}\right)$, methane $\left(\mathrm{CH}_{4}\right)$ and Hydrogen sulphide $\left(\mathrm{H}_{2} \mathrm{~S}\right)$. At the same time, only one such a hydrothermal source emits Carbon dioxide and methane 30 times more than all the industrial factories of the World. The emitted gases are not kept in pure sea water, and come into the natural circulation. Hence the bottom of oceans has thousands of the mentioned hydrothermal sources, even the limitation of greenhouse gas emission with accordance to Kyoto agreement or even stopping all the industry will not reduce the process of global warming on the planet ${ }^{15}$.

\section{Results of the study}

The problem of agricultural production in connection with the intensive tempo of global and local change in climate at the moment is sharpened that is manifested through the increase of average annual air temperature, intensive natural disasters, including drought, occupying up to $50-70 \%$ of the territory of Ukraine. The analysis of long-term observations on the weather conditions conducted by Kherson meteorological station in Southern part of the Steppe zone allowed determination and absolute value of hydrothermal indexes in different by humidification years. On average for 65 years of

15 Киотский протокол. [Электронный ресурс]. Ограничение выбросов парникових газов на планете. Режим доступа: Internet resources: http: // echo. msk.ru/news/511753echo.html. 
observations (1945-2010) evapotranspiration was $722.0 \mathrm{~m}$, and moisture deficit did not surpass $487.4 \mathrm{~mm}$ (Fig. 1).

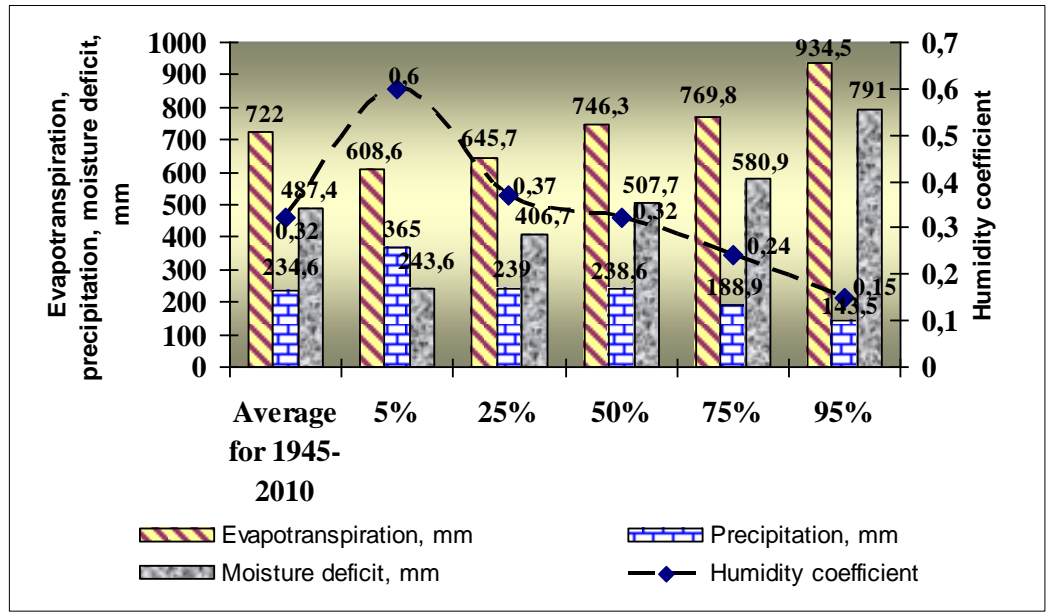

Fig. 1. Hydrothermal indexes of vegetation period of crops in different years by the precipitation supply (by the data of Kherson meteorological station)

In the humid (5\%) years evapotranspiration did not overscore $608.6 \mathrm{~mm}$, respectively, moisture deficit decreased to $243.6 \mathrm{~mm}$. In the moderately humid $(25 \%)$ and moderate $(50 \%)$ years evapotranspiration increases to 645.7-746.3 mm, and moisture deficit increases to 406.7-507.7 $\mathrm{mm}$. In the moderately dry (75\%) and dry (95\%) years evapotranspiration increases to 769.8-934.5 mm, and moisture deficit - to 580.9-791.0 $\mathrm{mm}$.

Humidity coefficient calculated by the indexes of Kherson and Askanian meteorological stations during the vegetation period of crops coincide in general. On average for 1945-2010 humidity coefficient in April was 0.390.43; May - 0.39; June - 0.37; July - 0.26; August - 0.19-0.22 and September $-0.29-0.37$. The highest indexes of humidity coefficient were revealed in April - 0.39-0.43 and September - 0.29-0.37, and the lowest ones were in July -0.26 and August 0.19-0.22 (Fig. 2). 


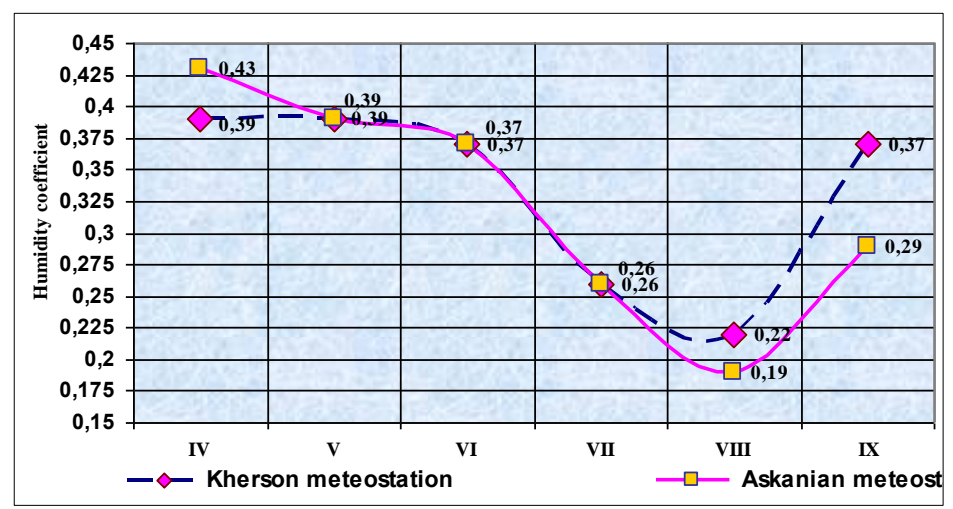

Fig. 2. Humidity coefficient during the vegetation period of perennial herbs (April-September) (by the data of Kherson and Askanian meteorological stations, average for 1945-2010)

The decrease of humidity coefficient during the last years takes place together with significant increase in average month temperature and decrease of relative air humidity. The increase of average month temperature testifies about significant change of heat, air and radiation regimes in the sub-zone of Southern Steppe during the vegetation period of dry (95\%) 2017 year (Fig. 3).

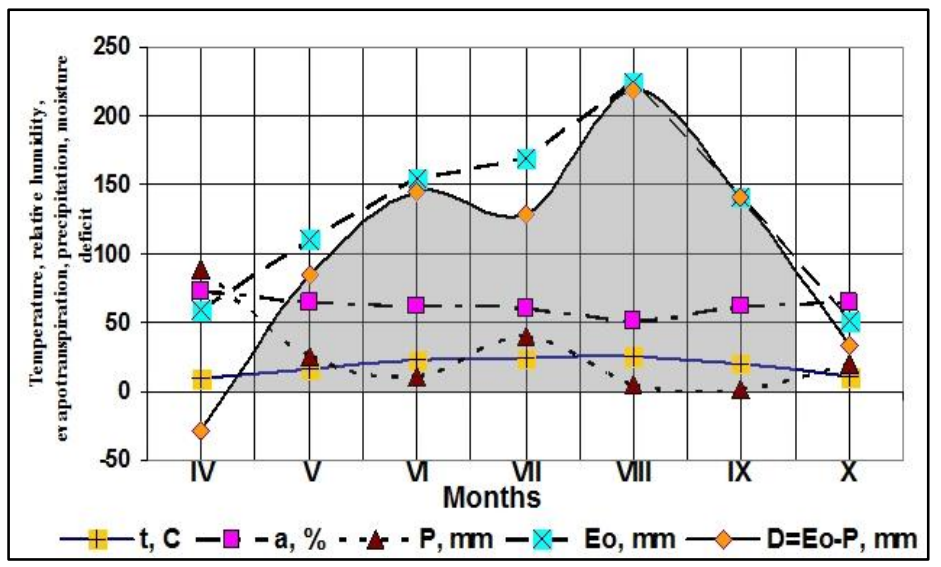

Fig. 3. Hydrothermal indexes of the vegetation period of crops in dry (95\%) 2017 year (the zone colored grey is the area equaling the moisture deficit of crops) 
On the whole, moisture deficit during the vegetation period of crops was $690.0 \mathrm{~mm}$ and, compared to the perennial indexes, it was higher by $81.2 \mathrm{~mm}$ or $16.0 \%$. At the same time, it reached in May $84.9 \mathrm{~mm}$; in June - 144.8; in July - 128.9; in August - 219.2 and in September - $140.8 \mathrm{~mm}$. Humidity coefficient in dry (95\%) 2017 year on average for the vegetation period was 0.20 including: in April - 1.48; in May - 0.23; in June - 0.07; in July - 0.24; in August - 0.02 and in September - 0.01 (Fig. 4).

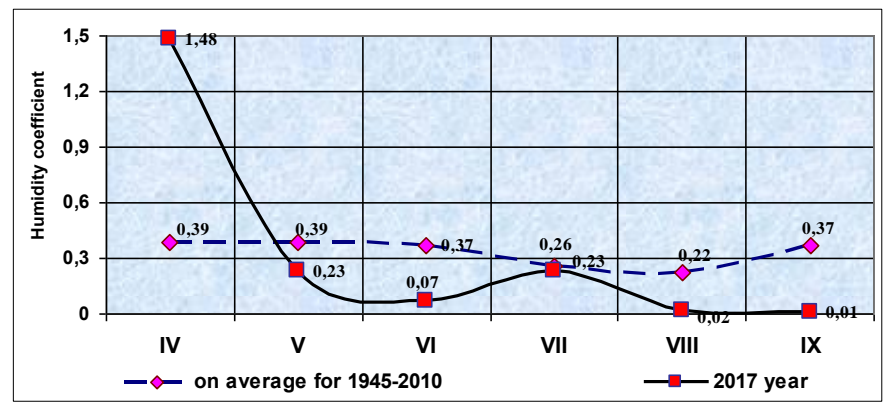

\section{Fig. 4. Humidity coefficient during the vegetation period of crops in dry $(95 \%) 2017$ year and on average for 1945-2010 (by the data of Kherson meteorological station)}

According to N.N. Ivanov ${ }^{16}$ the indexes presented testify about the fact that the territory of Southern part of the Steppe zone by the humidity coefficient during May-September in dry (95\%) 2017 year belonged to semi-arid and arid zone. On average for 65 years of observation (1945-2010) precipitation amount in winter (XII-II months) did not over score $93.0 \mathrm{~mm}$, respectively, in spring (III-V) - 93.7; summer (VI-VIII) - 126.3 and autumn (IX-XI months) $102.7 \mathrm{~mm}$. During the vegetation period (April-September) precipitation amount on average for 1945-2010 was $232.7 \mathrm{~mm}$, respectively, in $2011-185.5 \mathrm{~mm}$; 2012 - 186.6; 2013 - 154.2; 2014 - 218.5; 2015 - 315.2; 2016 - 277.7 and in $2017-169.1 \mathrm{~mm}$.

Precipitation amount, which has fallen during 2011-2017, in moderately dry (75\%) and dry (95\%) years testifies that in comparison to the average long-term one in 1945-2010 it was significantly lower and did not exceed 47.2-63.6 mm. If on average for 1945-2010 precipitation amount was $232.7 \mathrm{~mm}$, then in 2011 its amount was $185.5 \mathrm{~mm}$, respectively, in 2012 - 186.6; 2013 - 154.2; 2014 218.5; 2015 - 315.3; 2016 - 277.7 and in 2017 - $169.1 \mathrm{~mm}$ (Fig. 5).

16 Иванов Н. Н. Показатель биологической эффективности климата. Известия Всесоюзного географического общества. 1962. Т. 94. Вып. 1. С. 65-70. 


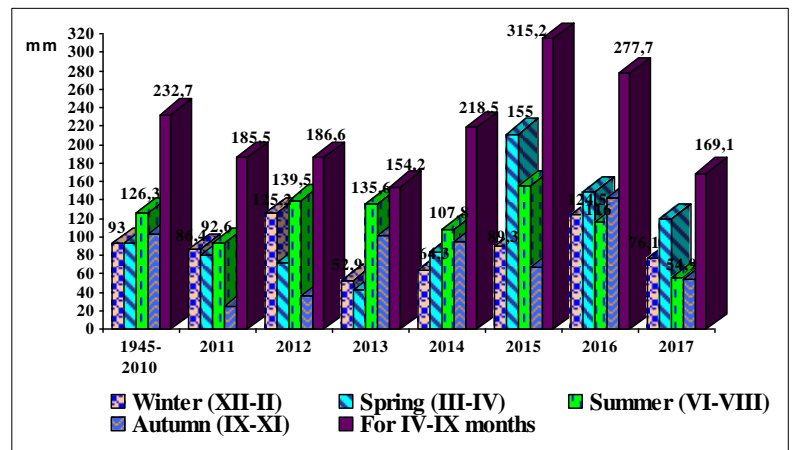

Fig. 5. Precipitation amount in different years during the vegetation period of crops (April-September) and by the seasons in the sub-zone of Southern Steppe Of Ukraine (by the data of Kherson meteorological station)

The decrease of precipitation in the spring period in dry (95\%) 2012 year, in comparison to 1945-2010, by $22.6 \mathrm{~mm}(24.1 \%)$ and in the autumn - by $66.4 \mathrm{~mm}$ $(64.6 \%)$ at the simultaneous increase of the air temperature in the mentioned periods of the year by $2.7^{\circ} \mathrm{C}$ and $2,8^{\circ} \mathrm{C}$ in general for the vegetation period (IV-IX months) led to the increase of evapotranspiration by $217.5 \mathrm{~mm}(29.9 \%)$ and moisture by $263.6 \mathrm{~mm}$, or by $53.4 \%$.

Evapotranspiration and moisture deficit during 2011-2017 significantly changed and depended on the average month temperature and relative air humidity and precipitation amount (Fig. 6).

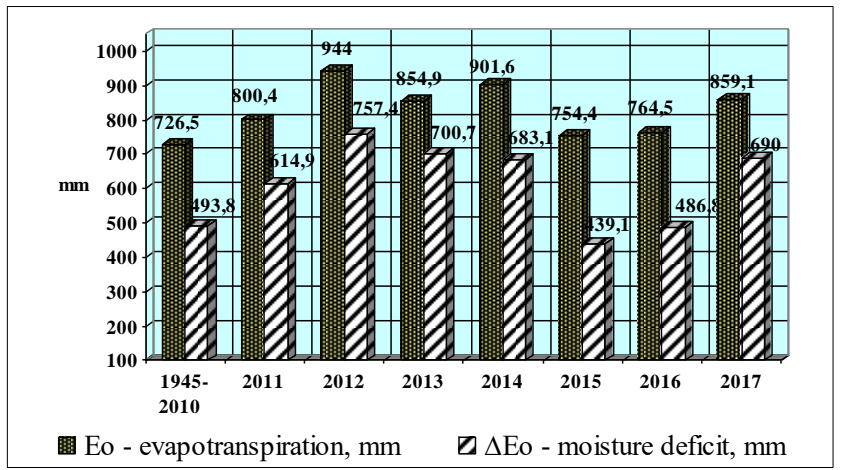

Fig. 6. Evapotranspiration (Eo) and moisture deficit ( $\Delta$ Eo) during the vegetation period (IV-IX months) of crops in the sub-zone of Southern Steppe (by the data of Kherson meteorological station) 
Under such weather conditions, which were during 2011-2017, there was an intensive spreading of the most harmful quarantine weed - ragweed (Ambrosia artemisifolia) - in Kherson region ${ }^{17}$ that caused significant decrease of the cultivated crops.

Together with significant effect on the crop formation, regional changes in climate at the end of XX and at the beginning of XXI century were also favorable for intensive development of agriculture in Southern part of the Steppe zone that is connected with high plowing rate of the agricultural land and their degradation ${ }^{18}$.

Systematic enlargement of the plow-lands in Ukraine during XX century resulted in unstable state of agricultural landscapes, plowing rate of which at the beginning of XXI century reached in the Steppe zone 81.3\%, and in a number of regions it is the highest in the world scale: Kherson $-90.2 \%$, Kirovohrad - 86.8; Mykolaiv - 84.6; Zaporizhzhia - 84.2; Dnipropetrovsk 84.0; Donetsk - 81.0; Odesa - 80.2 and Luhansk - 72.0\% (Fig.7).

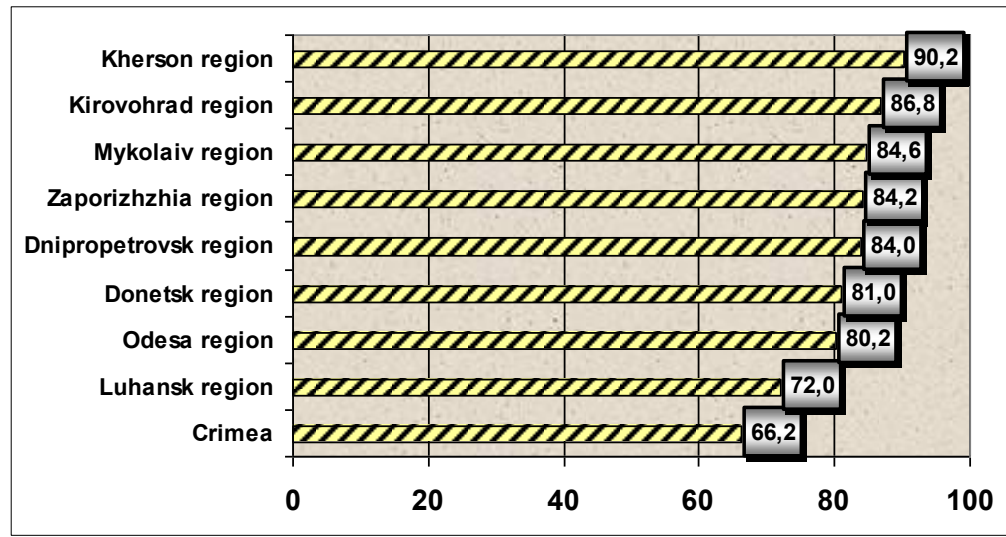

Fig. 7. Ratio of the arable land that is used in agriculture (arable land + perennial plantings) to the total agricultural land area in the regions of the Steppe zone of Ukraine, \%

In a number of districts of Kherson region plowed lands areas were much higher: Hornostaivka - 97.9\%; Nyzhni Sirohozy - 96.3; Velykolepetykha 96.0; Novovorontsovka - 94.6; Chaplynka - 94.0; Henichesk - 93.6;

${ }^{17}$ Косолапов Н., Андерсон Р. Как обуздать амброзию. Зерно. 2008. № 7. С. 60-66.

${ }^{18}$ Статистичний щорічник Херсонської області за 2006 рік. Херсон, 2007. С. 119-120. 
Kakhovka - 92.3; Verkhni Rohachyk - 92.0; Bilozerka - 91,5; Velykooleksandrivka -91.1 and Beryslav - 90.6\%.

The main reason of soil degradation as a complex of a number of negative processes that lead to significant decrease of fertility in the subzone of Southern Steppe of Ukraine are wind and water erosion, salinization, swamping, land use and pollution with radioactive elements.

Long-term use in Southern part of the Steppe zone of scientifically not proved systems of agriculture led to exceeded plowing of the soil surface, and, correspondingly, to the intensive soil erosion and irrational use of land resources in general.

At the total area of arable land of 15,528.7 thousand ha in connection with the excluded from the croplands forage crops, leguminous ones and perennial cereal herbs firstly, the area of eroded lands in the Steppe zone increased during the last years up to $8,636.8$ thousand ha, or $55.6 \%$ of the total arable land area (Table1).

Table 1

Areas of the eroded lands in the regions of the Steppe zone and in Ukraine on the whole, thousand ha ${ }^{19}$

\begin{tabular}{|c|c|c|c|c|c|c|}
\hline \multirow{2}{*}{ Region } & \multirow{2}{*}{$\begin{array}{c}\text { Agricultu } \\
\text { ral land }\end{array}$} & \multirow{2}{*}{$\begin{array}{c}\text { Arable } \\
\text { land }\end{array}$} & \multicolumn{4}{|c|}{ Eroded lands } \\
\cline { 4 - 7 } & & & \multicolumn{2}{|c|}{ Agricultural land } & \multicolumn{2}{|c|}{ Arable land } \\
\cline { 4 - 7 } & $1,798.4$ & $1,265.6$ & 999.3 & 55.6 & 919.3 & 72.6 \\
\hline Crimea & $2,514.3$ & $2,125.0$ & $1,104.8$ & 43.9 & 914.7 & 43.0 \\
\hline Dnipropetrovsk & $2,045.2$ & $1,656.0$ & $1,757.4$ & 85.9 & $1,080.0$ & 65.2 \\
\hline Donetsk & $2,247.7$ & $1,906.7$ & $1,212.5$ & 53.9 & 640.8 & 33.6 \\
\hline Zaporizhzhia & $2,039.9$ & $1,762.4$ & $1,102.4$ & 54.0 & 886.7 & 50.3 \\
\hline Kirovohrad & $1,911.1$ & $1,269.7$ & $1,372.3$ & 71.8 & $1,237.9$ & 97.5 \\
\hline Luhansk & $2,010.0$ & $1,698.1$ & 964.5 & 48.0 & 914.8 & 53.9 \\
\hline Mykolaiv & $2,593.4$ & $2,067.6$ & $1,214.0$ & 46.8 & $1,081.6$ & 52.3 \\
\hline Odesa & $1,971.1$ & $1,777.6$ & 686.2 & 34.8 & 961.0 & 54.1 \\
\hline Kherson & $\mathbf{1 9 , 1 3 1 . 1}$ & $\mathbf{1 5 , 5 2 8 . 7}$ & $\mathbf{1 0 , 4 1 3 . 4}$ & $\mathbf{5 4 . 4}$ & $\mathbf{8 , 6 3 6 . 8}$ & $\mathbf{5 5 . 6}$ \\
\hline Total & $\mathbf{4 1 , 5 9 5 . 1}$ & $\mathbf{3 2 , 4 6 1 . 4}$ & $\mathbf{1 5 , 9 5 3 . 9}$ & $\mathbf{3 8 . 4}$ & $\mathbf{1 2 , 9 4 0 . 3}$ & $\mathbf{3 9 . 9}$ \\
\hline $\begin{array}{c}\text { On the whole in } \\
\text { Ukraine }\end{array}$ & & & & & & \\
\hline
\end{tabular}

The consequent of the use in modern farming conditions of scientifically not proven system of agriculture is yearly increase of the areas with moderately and heavy washed out, deflation dangerous soils and the loss of land resources in general, where the degraded landscapes began to form. The latter is connected with disforesting of forest belts and forests.

${ }^{19}$ Балюк С. А., Медведєв В. В., Тараріко О. Г. та ін. Національна доповідь "Про стан родючості грунтів України”. Посібник украӥнського хлібороба. Київ, 2011. С. 41-69. 
As a consequent of intensive arable land use during the last years significant decrease of water interchange between the surface and subsurface waters occurred that is connected with the manifestation of water and wind erosion of soil causing the changes in the ratio of income and expenses shares of water balance. Due to the mentioned natural changes, in the recent years most regions of Southern part of the Steppe zone suffer from severe soil moisture deficit that is an obstacle for obtaining high crops ${ }^{20}$.

Together with high area of plowed land and not taking into account scientifically proven systems of agriculture, a significant effect on agricultural industry in the sub-zone of Southern Steppe regional change in climate occurred, especially in dry (95\%) years (Fig. 8).

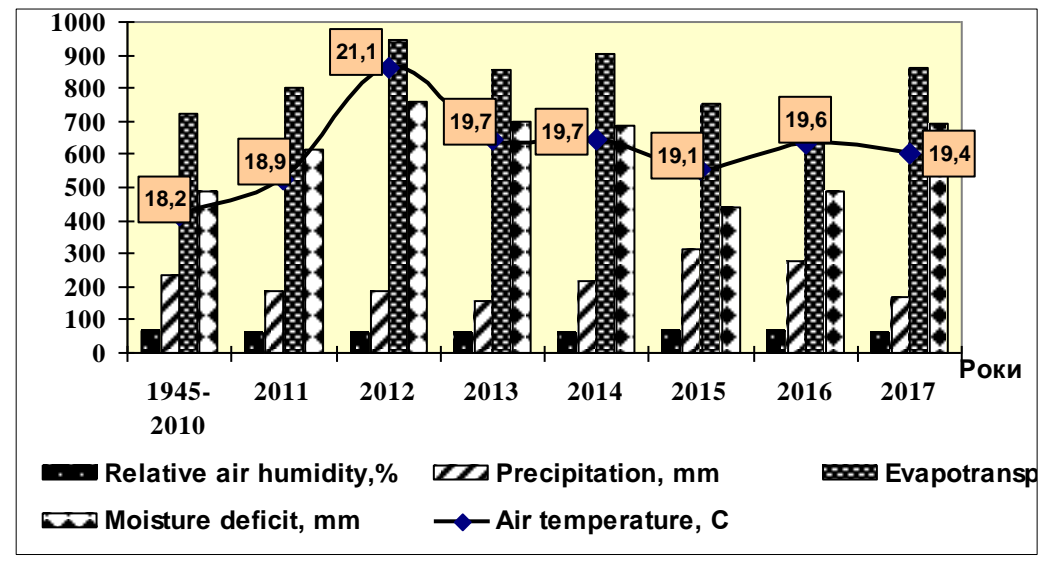

Fig. 8. Change of hydrothermal indexes during the vegetation period of crops in the sub-zone of Southern Steppe, on average for 1945-2010 and 2011-2017 (by the data of Kherson meteorological station)

The analysis of the average daily air temperature, conducted during the vegetation period of crops over the last 70 years in Southern part of the Steppe zone, shows that during 2011-2017, compared to the average of 65 years (1945-2010), it was significantly different. Herewith, the increase in average monthly air temperature occurred in the spring, summer and autumn. In the spring months (III-V), the air temperature was higher by $2.7^{\circ} \mathrm{C}$ or $28.4 \%$, respectively, in summer (VI-VIII, compared to the average

20 Комплексна галузева програма "Розвиток зерновиробництва в Україні до 2015 року” [Електронний ресурс]. Режим доступу: http://www.agro-business.com. ua/component/content / article/878.html?ed=55. 
long-term over the 65 years $(1945-2010)$. ) $-2.8^{\circ} \mathrm{C}$, or $12.9 \%$, and autumn (IX-XI) $-3.3^{\circ} \mathrm{C}$, or $32.3 \%$. Simultaneously with the increase in air temperature in the summer period of the year, the higher duration of the air temperature above $30^{\circ} \mathrm{C}$ increased significantly.

Thus, in the conditions of Kherson region in 2011, due to the amount of precipitation that fell during the autumn vegetation period of winter wheat equaled to only $25.1 \mathrm{~mm}$, the humidity coefficient did not exceed 0.07 that is usual for the desert. During the spring-summer period of its vegetation in 2012, with a rainfall of $65.6 \mathrm{~mm}$, there was also a significant shortage of moisture supply, resulting in extremely low winter wheat yields, and sometimes it completely died (Fig. 9).

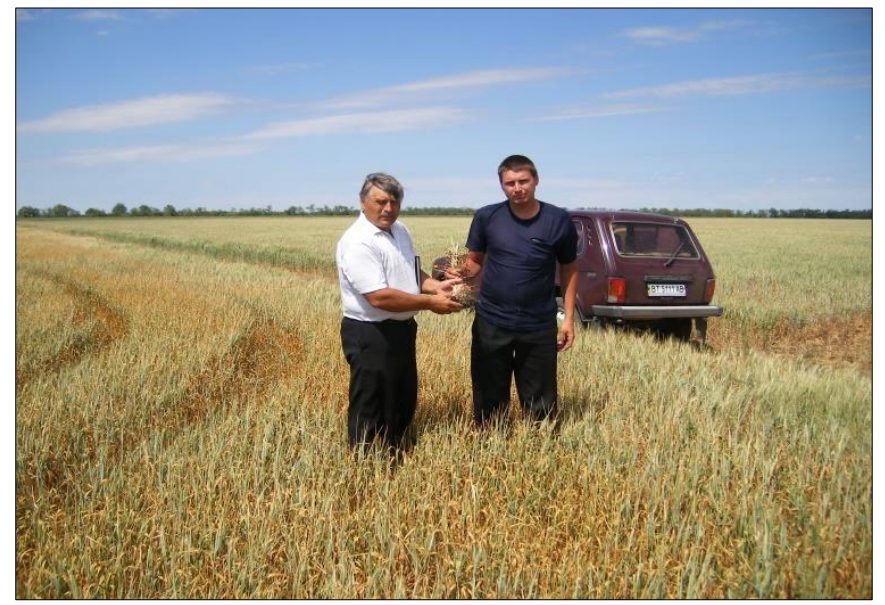

Fig. 9. Crops of winter wheat variety Kuialnik at the non-irrigated lands of State Enterprise Research Farm «Kopani» of the Institute of Irrigated Agriculture of NAAS in the conditions of air and soil drought in 2012

One of the maindirections that contribute in the current economic conditions to obtaining of high stable crops in Southern part of the Steppe zone is the optimization of the cropland structure and the increase of soil fertility. In developed countries of the world, this problem is solved by removing degraded and unproductive arable lan from intensive tillage, covering them with perennial leguminous herbs and legume-cereal herb mixtures and afforestation.

In this regard, long-term scientific research on the breeding of perennial leguminous herbs, the biological characteristics of which are most adapted to 
the natural and climatic conditions of the sub-zone of Southern steppe, have been carried out at the Institute of Irrigated Agriculture of NAAS. The studies showed that the accumulation of symbiotic nitrogen by alfalfa and sainfoins depended on the dry matter yield, nitrogen content in the plants, water supply deficits and the duration of the herbage use in years (Table 2).

Table 2

Accumulation of symbiotic nitrogen by alfalfa and sainfoins in Southern Steppe of Ukraine (average for the three years of the study)

\begin{tabular}{|c|c|c|c|c|c|c|}
\hline \multirow{2}{*}{ Indexes } & \multicolumn{3}{|c|}{ Alfalfa (Unitro) } & \multicolumn{3}{|c|}{ Sainfoins (Inhulskyi) } \\
\hline & $\mathbf{A}$ & $\mathbf{B i}$ & $\mathbf{A}+\mathbf{B i}$ & $\mathbf{C B}$ & & \\
\hline \multicolumn{7}{|c|}{ The first year of use } \\
\hline Nitrogen uptake by the crop: $\mathrm{kg} / \mathrm{ha}$ & 179 & 119 & 187 & 237 & 119 & 224 \\
\hline$\%$ & 150 & 100 & 157 & 199 & 100 & 188 \\
\hline Including biological, $\mathrm{kg} / \mathrm{ha}$ & 60 & - & 68 & 118 & - & 105 \\
\hline Nitrogen fixation coefficient, $\%$ & 33.5 & - & 36.4 & 49.8 & - & 46.9 \\
\hline Equivalent to mineral nitrogen: $\mathrm{kg} / \mathrm{ha}$ & 174 & - & 198 & 343 & - & 305 \\
\hline $\mathrm{GJ} / \mathrm{ha}$ & 15.1 & - & 17.2 & 29.7 & - & 26.5 \\
\hline \multicolumn{7}{|c|}{ The second year of use } \\
\hline Nitrogen uptake by the crop: kg/ha & 174 & 119 & 156 & 203 & 123 & 175 \\
\hline$\%$ & 146 & 100 & 131 & 165 & 100 & 142 \\
\hline Including biological, $\mathrm{kg} / \mathrm{ha}$ & 55 & - & 37 & 80 & - & 52 \\
\hline Nitrogen fixation coefficient, $\%$ & 31.6 & - & 23.7 & 39.4 & - & 29.7 \\
\hline Equivalent to mineral nitrogen: $\mathrm{kg} / \mathrm{ha}$ & 160 & - & 107 & 233 & - & 151 \\
\hline GJ/ha & 13.9 & - & 9.3 & 20.2 & - & 13.1 \\
\hline \multicolumn{7}{|c|}{ The third year of use } \\
\hline Nitrogen uptake by the crop: $\mathrm{kg} / \mathrm{ha}$ & 150 & 114 & 151 & 125 & 110 & 132 \\
\hline$\%$ & 132 & 100 & 132 & 114 & 100 & 120 \\
\hline Including biological, $\mathrm{kg} / \mathrm{ha}$ & 36 & - & 37 & 15 & - & 22 \\
\hline Nitrogen fixation coefficient, $\%$ & 24.0 & - & 24.5 & 12.0 & - & 16.7 \\
\hline Equivalent to mineral nitrogen: $\mathrm{kg} / \mathrm{ha}$ & 105 & - & 108 & 44 & - & 64 \\
\hline GJ/ha & 9.1 & - & 9.3 & 3.8 & - & 5.5 \\
\hline
\end{tabular}

Note: $A$-alfalfa; $B i$-bromus inermis; $A+B i$-alfalfa + bromus inermis; $S$-sainfoins; $S+B i-$ sainfoins + bromus inermis

The yield of absolutely dry matter of the herb mixtures of alfalfa + bromus inermis in the years of the study did not exceed 4.34-5.08 t/ha and sainfoins 3.86-6.12 t/ha. The nitrogen uptake by the crop depended on the species composition of plants and the year of use of the herbage and reached: alfalfa $-150-179 \mathrm{~kg} / \mathrm{ha}$, sainfoins $-125-237$; alfalfa herb mixture + bromus inermis - 151-187 and sainfoins + bromus inermis $-132-224 \mathrm{~kg} / \mathrm{ha}$.

In the first year of the herbage use, symbiotic nitrogen accumulation by the crops of single-species alfalfa reached $60 \mathrm{~kg} / \mathrm{ha}$ and $68 \mathrm{~kg} / \mathrm{ha}$ in the alfalfa herb mixture + bromus inermis, with a nitrogen fixation coefficient of $33.5 \%$ and $36.4 \%$, respectively. It was found that the accumulation of symbiotic nitrogen in the above-mentioned volumes by alfalfa and alfalfa herb mixture was equivalent to $174-198 \mathrm{~kg} / \mathrm{ha}$ of mineral nitrogen in the 
form of ammonium nitrate, or 15.1-17.2 GJ/ha of total energy. Sainfoins at a nitrogen fixation coefficient of $46.9-49.8 \%$ accumulated $105-118 \mathrm{~kg} / \mathrm{ha}$ of symbiotic nitrogen, equivalent to $305-343 \mathrm{~kg} / \mathrm{ha}$ of mineral nitrogen, or 26.5-29.7 GJ/ha of total energy.

In the second year of the use, symbiotic nitrogen accumulation in both alfalfa and sdainfoins was also high, reaching $37-55 \mathrm{~kg} / \mathrm{ha}$ in alfalfa and $52-80 \mathrm{~kg} / \mathrm{ha}$ in sainfoins, with a nitrogen fixation coefficient of $23.7-31.6 \%$, and $29.7-39.4 \%$, respectively. Symbiotic nitrogen accumulation of alfalfa in the mentioned volumes was equivalent to mineral within $107-160 \mathrm{~kg} / \mathrm{ha}$, or 9.3-13.9 $\mathrm{GJ} / \mathrm{ha}$ of total energy against $151-233 \mathrm{~kg} / \mathrm{ha}$ in sainfoins, or 13.1-20.2 GJ/ha of total energy.

In the third year of the perennial legumes herbage use, accumulation of symbiotic nitrogen by alfalfa decreased to $36-37 \mathrm{~kg} / \mathrm{ha}$ and to $15-22 \mathrm{~kg} / \mathrm{ha}$ at sainfoins, which is connected with the changes in the species botanical composition of the sown herbs. Due to a significant decrease of the part in the botanical composition of speciesboth in the single-species and herb mixtures of sainfoins, accumulation of symbiotic nitrogen in a mineral form equivalent in sainfoins was only $44-64 \mathrm{~kg} / \mathrm{ha}$ or $3.8-5.5 \mathrm{GJ} / \mathrm{ha}$, against $105-108 \mathrm{~kg} / \mathrm{ha}$ at alfalfa, or $9.1-9.3 \mathrm{GJ} / \mathrm{ha}$ of total energy.

\section{CONCLUSIONS}

The intensive pace of global and regional climate change in the sub-zone of Southern Steppe is now significantly exacerbated, which is manifested by the increase in average annual air temperatures, extreme weather phenomena, including droughts, which cover up to 50-70\% of its territory. Alongside with the significant impact of global climate change on the formation of high yields, the extremely high plowing of existing agrolandscapes also led to their degradation.

The cultivation of mono-species crops of alfalfa and sainfoins and their herb mixtures with bromus inermis in the three-year period of their use allowed obtaining green forage, balanced with digestible protein without mineral fertilizers, and having the best previous crops for cereals during the three years of their cultivation.

Creation of high-yielding mono-species crops of perennial leguminous herbs and binary legume-cereal herb mixtures contributed to a significant increase in the content of mineral and alkalinely hydrolyzed nitrogen compounds, the improvement of the physical and physico-chemical properties of soils and, first of all, the significant diminishing of the catastrophic effect of natural phenomena, connected with global and regional climate change. 
Therefore, increasing soil fertility and their protection at the moment in the sub-region of Southern Steppe, as well as in Ukraine on the whole, is one of the most important fundamental problems, solving of which will ensure long-term sustainable development and high productivity of agro-ecological systems under the preservation of agricultural agrolandscapes, their soil cover.

\section{SUMMARY}

The analysis of global climate change and its influence on the increase of hydrothermal indicators during the vegetation period of crops in Southern Steppe of Ukraine was carried out. It was found that the average rainfall during 2011-2017 in the moderately dry (75\%) and dry (95\%) years was significantly lower and averaged to $154.2-186.6 \mathrm{~mm}$ versus $232.7 \mathrm{~mm}$ in the average for the years 1945-2010. The decrease of precipitation amounts in the last years in the spring by $24-27 \%$ and in the autumn by $62-65 \%$, with a simultaneous increase in temperature and decrease in the relative humidity in these seasons by $2.7-2.8^{\circ} \mathrm{C}$, led to an increase in evapotranspiration by 30 $31 \%$ and a deficit in water supply by $53-55 \%$. It is proved that the increase of soil fertility in the sub-zone of Southern Steppe, as well as in Ukraine on the whole, is one of the most important fundamental problems, solving of which will ensure long-term sustainable development and high productivity of agro-ecological systems under the preservation of their agrolandscapes, and first of all, of their soil cover. The feasibility of the creation of monospecies crops of alfalfa and alfalfa-cereal herb mixtures has been substantiated, which will significantly increase the content of mineral compounds of nitrogen and reduce the catastrophic impact of natural phenomena associated with global climate change. Efficient use and further expansion of the cropland areas under alfalfa in the conditions of global climate changes will contribute to the enhancement of soil fertility, higher crops, which will provide stable food security for the population of Ukraine.

\section{REFERENCES}

1. Исследования межгосударственной группы экспертов при ООН. [Электронный ресурс]. Начало повышения температуры на планете. Режим доступа: Internet resources: http://ru.wikipedia.org/wiki/.

2. Влияние парниковых газов на глобальное изменение климата. [Электронный pecypc]. Причины нагревания поверхности Земли. Режим доступа: Internet resources: http://www.referatik.com.ua/subject/97/ $41350 /$ ?page $=2$. 
3. Гидрологический словарь. Под ред. В.М. Котлякова. Л. : Гидрометиздат, 1984. 527 с.

4. Концентрация углекислого газа в атмосфере. [Электронный pecypc]. Изменение структуры агроландшафтов. Режим доступа: Internet resources: http://enrin.grida.no/htmls/tadjik/ntalgraphics/rus/ html/climate.htm.

5. Источники загрязнения атмосферы. [Электронный ресурс]. Ежегодные выбросы парниковых газов. Режим доступа: Internet resources: http://www.ukragroconsult.com/contentview/46301/61/.

6. Поглощение инфракрасной радиации. [Електронний ресурс]. Причины увеличения концентрации парникових газов. Режим доступу: www.un.org/ru/documents/decl_conv/conventions/agenda21_ch12b.shtml.

7. Мачерет Ю.П. Радиозондирование ледников. М.: Науч. мир, 2006. $392 \mathrm{c}$.

8. Причины увеличения метана в атмосфере. [Электронный ресурс]. Наличие градиента концентрации метана в межледниковые периоды. Режим доступа: Internet resources: http://www/lib/ua-ru/net/inode/p2/14290.html.

9. Природная изменчивость процесса Солнце-Земля. [Электронный pecypc]. Циклы изменения климата. Режим доступа: Internet resources: http://www.ukrindustrial.com./news/index.php.?newsid=219087.

10. Уменьшение площади ледников Арктики. [Электронный pecypc]. Усиление эрозии морских берегов. Режим доступа: Internet resources: http://www.zn.ua/3000/3320/63430/.

11. Фазы ледниковых периодов. [Электронный ресурс]. Продолжительность зимних периодов в Европе. Режим доступа: Internet resources: http://www.podrobnosti.ua.health/2008.08.22/548886. html.

12. Аномальне похолодання в Европе. [Электронный ресурс]. величение продолжительности зимного периода. Режим доступа: Internet resources: http://www.grida.no/climate/ipec_tor/vol14/russian/ 083.htm

13. Палеонтологические исследования. [Электронный ресурс]. Причины вымерания отдельных видов растений и животных. Режим доступа: Internet resources: http://imm.org.ua/se/news/index.php? action $=$ show $\&$ nid $=4163$

14. Bentley R. W. «Глобальное истощение нефти и газа: обзор». Energy Pochy. 2002. № 30. C. 189-205. 
15. Киотский протокол. [Электронный ресурс]. Ограничение выбросов парникових газов на планете. Режим доступа: Internet resources: http: // echo. msk.ru/news/511753-echo.html.

16. Иванов Н. Н. Показатель биологической эффективности климата. Известия Всесоюзного географического общества. 1962. Т. 94. Вып. 1. С. 65-70.

17. Косолапов Н., Андерсон Р. Как обуздать амброзию. Зерно. 2008. №7. C. 60-66.

18. Статистичний щорічник Херсонської області за 2006 рік. Херсон, 2007. С. 119-120.

19. Балюк С. А., Медведєв В. В., Тараріко О. Г. та ін. Національна доповідь "Про стан родючості грунтів України". Посібник украӥнського хлібороба. Київ, 2011. С. 41-69.

20. Комплексна галузева програма "Розвиток зерновиробництва в Україні до 2015 року" [Електронний ресурс]. Режим доступу: http://www.agro-business.com.ua/component/content/article/ 878.html?ed=55.

\section{Information about the author:} Holoborodko S. P., Doctor of Agricultural Sciences, Professor, Chief Researcher, Institute of Irrigated Agriculture of the National Academy of Agrarian Sciences of Ukraine Kherson, Naddniprianske, 73483, Ukraine 